\title{
The 24 July 2008 outburst flood at the western Zyndan glacier lake and recent regional changes in glacier lakes of the Teskey Ala-Too range, Tien Shan, Kyrgyzstan
}

\author{
C. Narama ${ }^{1}$, M. Duishonakunov ${ }^{2}$, A. Kääb ${ }^{3}$, M. Daiyrov ${ }^{2}$, and K. Abdrakhmatov ${ }^{4}$ \\ ${ }^{1}$ Research Institute for Humanity and Nature, Kyoto, Japan \\ ${ }^{2}$ Department of Physical Geography, Kyrgyz National University, Bishkek, Kyrgyzstan \\ ${ }^{3}$ Department of Geosciences, University of Oslo, Oslo, Norway \\ ${ }^{4}$ Institute of Seismology, Academy of Sciences of Kyrgyz Republic, Bishkek, Kyrgyzstan
}

Received: 20 August 2009 - Revised: 28 January 2010 - Accepted: 29 January 2010 - Published: 6 April 2010

\begin{abstract}
On 24 July 2008, a glacier lake outburst flood (GLOF) occurred at the western (w-) Zyndan glacier lake in the Tong District of Ysyk-Köl Oblast, Kyrgyzstan. The flood killed three people and numerous livestock, destroyed infrastructure, and devastated potato and barley crops as well as pastures. Tuurasuu village and a downstream reservoir on the Zyndan river escaped heavy damage because the main flood was diverted toward the Tong river. RTKGPS and satellite data (Landsat 7 ETM+, ALOS/PRISM, and ALOS/AVNIR-2) reveal that the flood reduced the lake area from $0.0422 \mathrm{~km}^{2}$ to $0.0083 \mathrm{~km}^{2}$, discharging $437000 \mathrm{~m}^{3}$ of water. This glacier lake was not present in a Landsat 7 ETM+ image taken on 26 April 2008. It formed rapidly over just two and half months from early May to the late July, when large amounts of snow and glacier melt water became trapped in a basin in the glacier terminus area, blocked by temporary closure of the drainage channel through the terminal moraine that included much dead-ice. In the same mountain region, most other glacier-lake expansions were not particularly large during the period from 1999-2008. Although events like the w-Zyndan glacier lake outburst occur infrequently in the high Central Asian mountains, such fast developing, short-lived lakes are particularly dangerous and not easy to monitor using satellite data. Appropriate measures to protect against such lake outburst hazards in this region include educating residents on glacier hazards and monitoring techniques, providing frequently updated maps of glacier lakes, and planning and monitoring land-use, including house locations.
\end{abstract}

Correspondence to: C. Narama (narama@chikyu.ac.jp)

\section{Introduction}

In the high mountains of Central Asia, glacier-related hazards such as glacier lake outburst floods (GLOFs) and glacier-ice avalanches frequently cause damage in downstream areas (Baimoldaev and Vinohodov, 2007; UNEP, 2007). A particularly large number of GLOF events were reported in the northern Tien Shan throughout the 1950s1970s (Kubrushko and Staviskiy, 1978; Kubrushko and Shatrabin, 1982). In the Kishi Almaty river of the Ile Ala-Tau range, northern Tien Shan, a glacier-lake flood developed on 15 July 1973 at the Tuyuksu glacier, killing 10 people in the downstream area (Baimoldaev and Vinohodov, 2007; Narama et al., 2009). More recently, a catastrophic flood occurred on 7 July 1998, with outburst from the ArchaBashy glacier lake in the Alay range of the Gissar-Alay region. This thermokarst lake, which had formed on a debriscovered dead-ice zone, released over $50000 \mathrm{~m}^{3}$ of water. The flood killed more than 100 residents in Shahimardan village in Uzbekistan (UNEP, 2007). In a similar event on $7 \mathrm{Au}-$ gust 2002 at the village of Dasht in the Shahdara valley, Pamir, Tajikistan, a glacier-lake outburst resulted in a debris flow that dammed the main river, killed 23 people and caused flooding (UNEP, 2007).

Clearly, glacier-related hazards can have severe downstream consequences, including killing and injuring people and livestock, damaging infrastructure, and devastating farmland. However, research and documentation are lacking on glacier-related hazards, processes, and consequences in Central Asia. In part, this lack of documentation reflects the fact that glacier-related floods in this region have been small in size, compared to those in the Himalayas, and locally restricted (Baimoldaev and Vinohodov, 2007). However, in

Published by Copernicus Publications on behalf of the European Geosciences Union. 


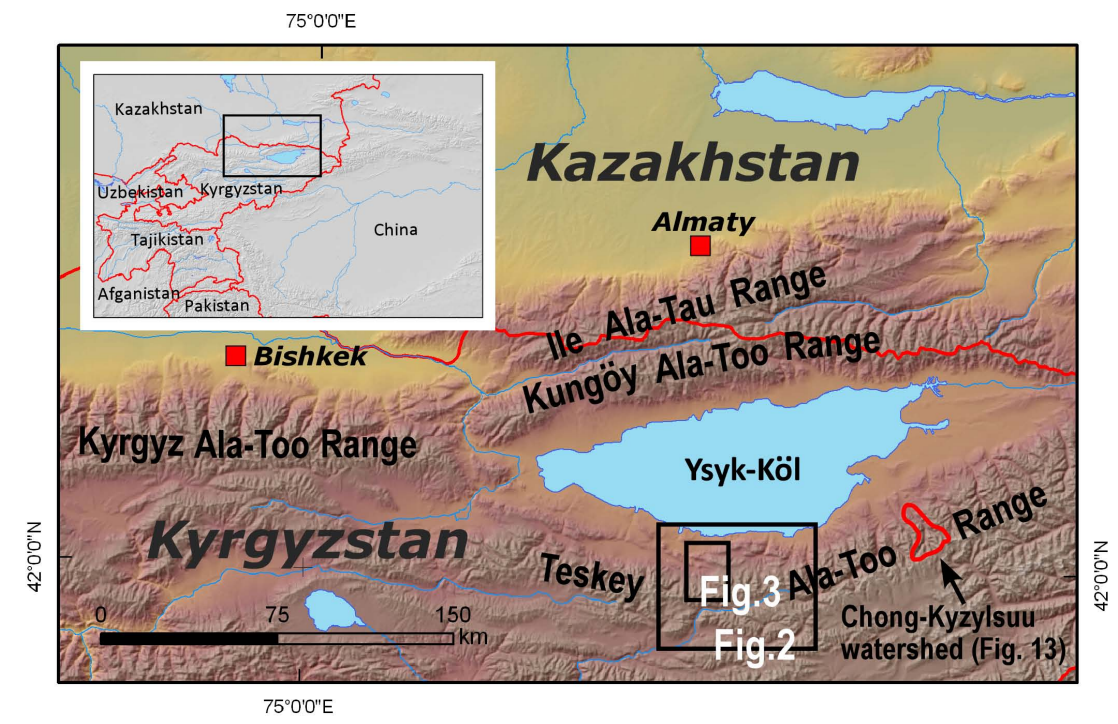

Fig. 1. Study area in the Teskey Ala-Too range along the south shore of the Lake Ysyk-Köl, Kyrgyzstan.

recent years, glacier lakes have been increasing in number and size (Narama et al., 2009), reflecting glacier melting in the outer Tien Shan mountains under atmospheric warming (Aizen, et al., 2006; Narama et al., 2006; Bolch, 2007; Kutuzov and Shahgedanova, 2009; Narama et al., 2010a) and posing growing threats to people living in and near the mountains. In this study, we researched the outburst of w-Zyndan glacier lake in the Teskey Ala-too range, Tien Shan, on 24 July 2008. We report on the causes, processes, and damages of the outburst and also discuss recent changes in glacier lakes in this region.

Our aim is to improve information on glacier-lake outbursts in a region where such events are not well documented and have occurred infrequently. We examine the characteristics of the $2008 \mathrm{w}$-Zyndan outburst, in which the glacier lake formed rapidly and was not recognized as a hazard, to provide specific hazard assessment and risk management strategies. In addition, we show how combinations of satellite and field data can be used to reconstruct a flood event from a relatively small, short-lived, and remote glacier lake.

\section{Study area}

The western (w-) Zyndan glacier lake $\left(41^{\circ} 56^{\prime} 38^{\prime \prime} \mathrm{N}\right.$, $77^{\circ} 01^{\prime} 20^{\prime \prime} \mathrm{E}$ ) is located on the northern flank of the Teskey Ala-Too range on the southern shore of Lake Issyk-Kul (Ysyk-Köl) in the northeastern Kyrgyz Republic (Kyrgyzstan; Figs. 1 and 2). In this mountain region, glaciers decreased in area by 8\% during 1971-2002 (Narama et al., 2006), and a number of glacier-lake outbursts and ice avalanches have been recorded since the 1970s (Fig. 2). Outburst floods from the Angy-Say glacier lake caused substantial flooding when drainage channels opened under the terminal moraine on 14 June 1974, 17 June 1975, and 25 June and 14 July 1980 (Fig. 3; Kubrushko and Staviskiy, 1978; Kubrushko and Shatrabin, 1982). The two floods in 1980 were especially powerful, but resulted in no downstream casualties. Discharge from the Tong river, which averages $2.2 \mathrm{~m}^{3} / \mathrm{s}$ annually $\left(6.9 \mathrm{~m}^{3} / \mathrm{s}\right.$ average for July 2002$)$ at the hydrological station, peaked at $35.0 \mathrm{~m}^{3} / \mathrm{s}$ during the flood on 24 July 1978 (no data are available for the flood origin site; Fig. 3; Yerokhin, 2008). Many local residents remember the Angy-Say GLOF events. On the south part of the Teskey Ala-Too range, local people witnessed that a GLOF occurred in the Kashka-Suu river (Fig. 2: No. 31), and that an ice avalanche occurred on the valley side of the Jyluu-Suu river in July-August 2006 (Fig. 2).

The w-Zyndan glacier, which is in contact with the wZyndan glacier lake, is about $1.2 \mathrm{~km}$ long and occupies $0.36 \mathrm{~km}^{2}$ (Fig. 3). The eastern (e-) Zyndan glacier (Fig. 2: No. 36), located in the same valley as the w-Zyndan glacier, is about $2.6 \mathrm{~km}$ long and occupies $1.50 \mathrm{~km}^{2}$. The e-Zyndan glacier is in contact with the e-Zyndan glacier lake. A zone of rocks and debris, presumably of morainic origin, and dead ice extends some $700 \mathrm{~m}$ downward from the w-Zyndan glacier front (Fig. 3). These glacier lakes have no surface outlet, and meltwater drains through the proglacial body of rock, debris, and ice. The lakes are located in the Tong District of Ysyk-Köl Oblast. The city of Bokonbaevo, the center of the Tong district, with a population of 10870 people, and the villages of Tort-Köl (population 2932) and Tuurasuu (population 723) are located downstream of the w-Zyndan glacier lake (Kudabaev et al., 2001; Fig. 3). The Zyndan river flows through Tuurasuu village and then into a reservoir built in 1990 to support irrigation and provide water for Tort-Köl. An artificial channel from the Zyndan river to the Tong river provides irrigation water for potato and barely fields from May to July. 


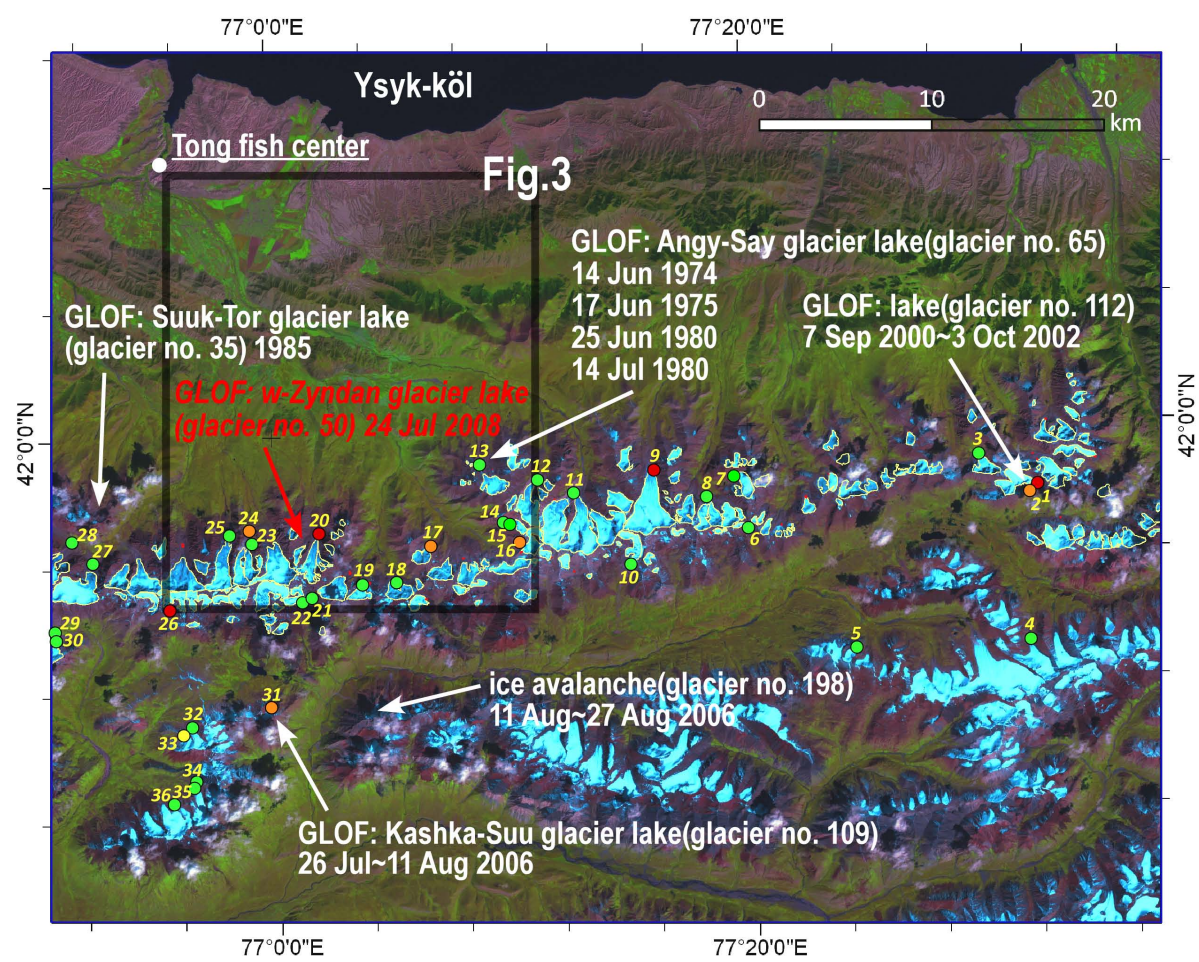

Fig. 2. The locations of glacier-lake outburst floods (GLOFs) since the 1970s in the Teskey Ala-Too range. Colored circles and numbers show the locations of the glacier lakes investigated during 1999-2008 in Fig. 4 (red circles: growing lakes $\left(>0.001 \mathrm{~km}^{2} / \mathrm{year}\right.$, orange circles: naturally drained lakes, green circles: no change).The glacier numbers were derived from the glacier inventory (Zabirov, and Sidikov, 1976; Fateev and Cheban, 1969).

\section{Methods}

\subsection{Regional glacier-lake analysis using satellite data}

We investigated the development of 36 glacier lakes $\left(>0.001 \mathrm{~km}^{2}\right)$ in the western part of the Teskey AlaToo range using satellite data (Landsat 7 ETM+ and ALOS/PRISM) between 1999 and 2008 to improve information on the recent status of glacier lakes in the region (Fig. 2). Landsat 7 Enhanced Thematic Mapper Plus (ETM+) images (9 September 1999, 9 July 2000, 26 June 2001, 3 October 2002, 20 September 2003, 21 August 2004, 7 July 2005, 12 September 2006, 15 September 2007, and 17 September 2008), and Panchromatic Remote-sensing Instrument for Stereo Mapping (PRISM) and Advanced Visible and Near-Infrared Radiometer type 2 (AVNIR-2) satellite data for 17 September 2007 from the Advanced Land Observing Satellite (ALOS) were used for continuous assessment for glacier-lake changes. Orthoprojection of the ALOS/AVNIR-2 satellite data was done using ground control points (GCPs) from ALOS/PRISM RPC orthorectified image and Shuttle Radar Topography Mission (SRTM) 3 data. The orthorectified Landsat (bands 3, 4, 5, and 8: panchromatic) and ALOS (AVNIR bands 2, 3, 4, and PRISM panchromatic) images were fused, and pan-sharpened images by the IHS model using PCI Geomatica version 10.2 software were used for extraction of the glacier-lake areas. GLOF events during the 1970s to 2000s in the Teskey Ala-Too range were analyzed based on fieldwork, satellite data, and previous studies (Kubrushko and Shatrabin, 1982; Yerokhin, 2008). We conducted field studies of several GLOFs in this region during 2006-2009. The area flooded by the Angy-Say GLOFs on 25 June and 14 July 1980 was mapped from orthorectified Corona KH-4 (23 September 1971) and Hexagon KH-9 (7 September 1980) satellite photographs (see Fig. 9).

\subsection{Field survey of the 2008 flood and satellite analysis of w-Zyndan glacier lake}

Field surveys of the drained w-Zyndan glacier lake and the downstream region were conducted from 26 July (2 days after the outburst) until 1 August 2008, on 23 September 2008, and again during 13-19 July 2009. We used a RTK-GPS900 system (Leica Geosystems) to determine the changes in the lake area and water level and also documented damage along the w-Zyndan river. The extent of the flood area was surveyed using GPS and ALOS/AVNIR-2 satellite image for 4 August 2008. We also interviewed seven families along the Zyndan river and several employees of the Tong Fish Center (Fig. 2) who were affected by the flood about the event and resulting damage. 


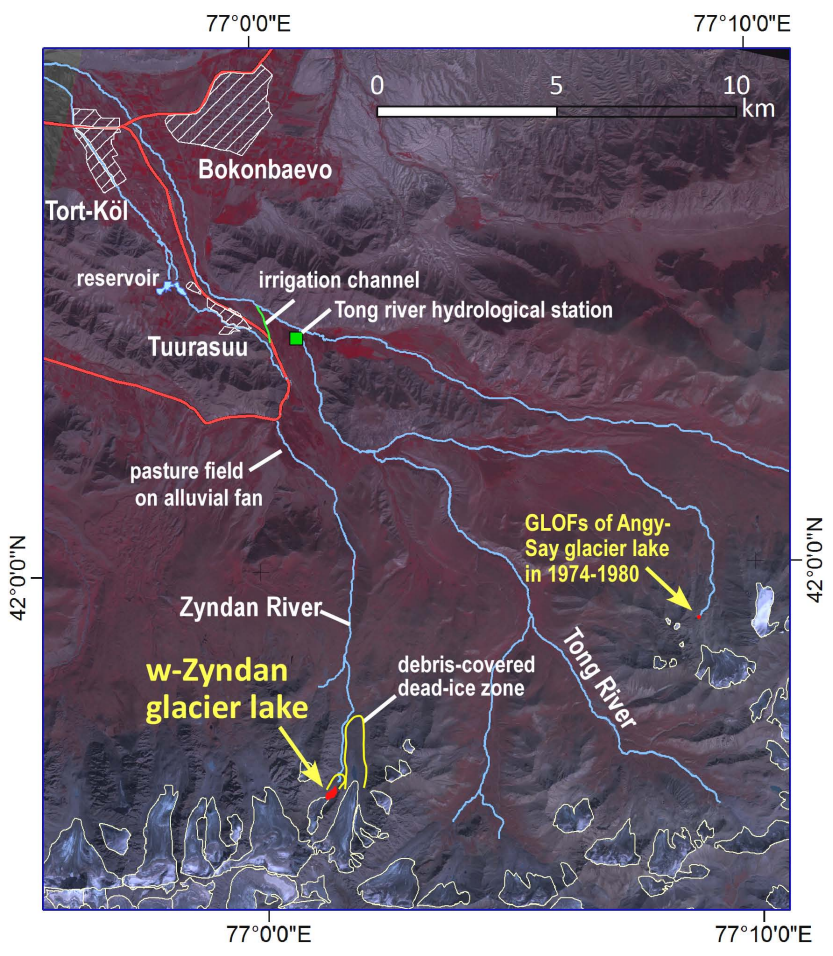

Fig. 3. Study area in the Zyndan river basin.

Changes in the w-Zyndan glacier-lake area were ascertained using pan-sharpened images of ALOS/PRISMAVNIR-2 data from 17 September 2007, ALOS/AVNIR-2 data from 19 June 2008, and Landsat 7 ETM+ data from 26 April 2008, 12 May 2008, 13 June 2008, 31 July 2008, 1 September 2008, and 17 September 2008. The study area is in the middle of a Landsat 7 ETM+ path, and thus data voids toward the image margins due to the current scan mirror failure (SLC off) did not affect our analyses. The glacier-lakes outlines were digitized manually in ArcGIS 9.3.

The volume changes of the w-Zyndan glacier lake were estimated using digital elevation models (DEMs) derived for the lake area using Leica RTK-GPS900 data (before and after the outbreak), Landsat 7 ETM+ data from 13 June 2008, and ALOS/AVNIR-2 data from 19 June 2008. Repeat longitudinal profiles of the w-Zyndan glacier surface were studied by comparing a DEM derived from a topographic map (1:25 000; 1966) using ArcGIS 9.3, the SRTM-3 DEM (2000), and a DEM derived from Leica RTK-GPS900 data (2008-2009). In the upstream of the Tong river, the differences between RTK-GPS data and the map DEM (1:25 000; $1966)$ were $1.3 \pm 3.0 \mathrm{~m}$ in non-glacier area. An SRTM DEM was also recently used to investigate elevation changes of small alpine glaciers in the Swiss Alps (Paul and Haeberli, 2008).

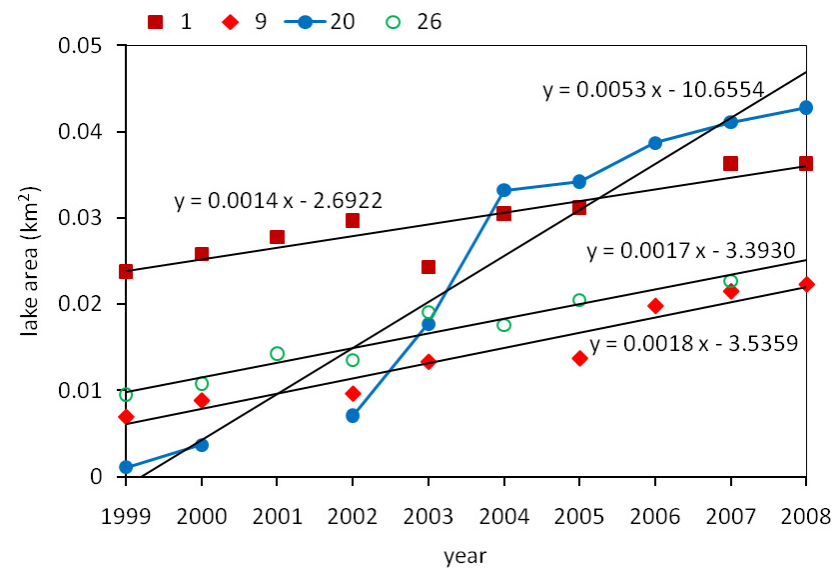

Fig. 4. Area changes of four growing glacier lakes in the Teskey Ala-Too range between 1999 and 2008. The locations of the lakes are shown in Fig. 2.

\section{Results}

\subsection{Expansion of glacier lakes in the western Teskey Ala-Too range}

We examined 36 glacier lakes around the w-Zyndan glacier lake in the western part of the Teskey Ala-Too range using pan-sharpened images from Landsat 7 ETM+ and ALOS/PRISM-AVNIR-2 over the period 1999-2008 (Fig. 2). Most glacier lakes showed no change or slight expansion. Four glacier lakes expanded remarkably, with expansion rates $>0.001 \mathrm{~km}^{2} /$ year during 1999-2008 (Fig. 4). The largest expansion, $0.0053 \mathrm{~km}^{2} /$ year, was found for the e-Zyndan glacier lake (Fig. 2: No. 36); this rate is still quite low when compared to expansion rates of 0.015 $0.030 \mathrm{~km}^{2} /$ year found in the Himalayas (Ageta et al., 2000; Komori et al., 2004). In the Kungöy Ala-Too and Ile Ala-Tau ranges of the northern Tien Shan (Fig. 1), the largest glacierlake expansion was $0.0059 \mathrm{~km}^{2} /$ year (Narama et al., 2009), similar to that in our study area.

In the study area, six glacier lakes (Nos. 2, 16, 17, 24, 31, and 33) produced small outburst floods during 1999-2008 (Fig. 2). Satellite data show remarkable changes in the lake areas and expansion of river channels with fresh flood deposits. Glacier lakes 16 and 33 increased rapidly following their GLOF events. According to local witnesses, no fatalities resulted from the GLOF of lake 31 between 26 July and 11 August 2006 in the Kashka-Suu river and damage was limited to flood deposits covering roads along the Jyluu-Suu river.

\subsection{Appearance of the w-Zyndan glacier lake}

Glacier lakes often take decades to develop to large size. The larger of the current Bhutan Himalayan glacier lakes, for example, have developed since the 1950s (Ageta et al., 2000). 


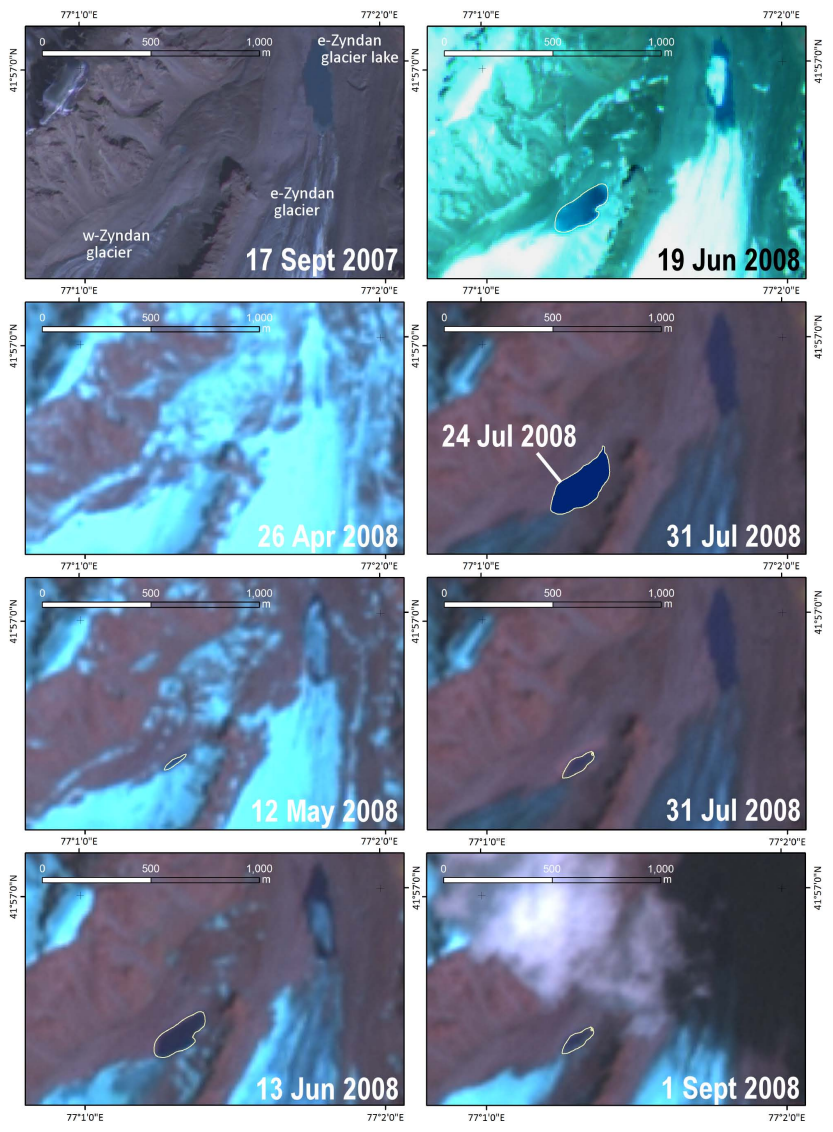

Fig. 5. Evolution of the w-Zyndan glacier lake between 17 September 2007 and 1 September 2008 as shown by satellite images (Landsat 7 ETM+, ALOS/PRISM-AVNIR-2, ALOS/AVNIR-2).

As another example, a mountain thermokarst lake on dead ice in the Swiss Alps took over 20 years to reach a critical size (Kääb and Haeberli, 2001). In the Ile Ala-Tau and Kungöy Alatoo ranges of the Tien Shan, most present glacier lakes have developed recently, since the 1980s (Narama et al., 2009). By contrast, the w-Zyndan glacier lake, which drained on 24 July 2008, was not present in satellite images on 17 September 2007 (ALOS/PRISM-AVNIR-2) and 26 April 2008 (Landsat 7 ETM+; Fig. 5). Its first appearance was on the glacier surface as a small pond of $0.0023 \mathrm{~km}^{2}$ on 12 May 2008 (Landsat 7 ETM+). By 13 June 2008, it had expanded to $0.0260 \mathrm{~km}^{2}$ (Landsat $7 \mathrm{ETM}+$ ), and continued to expand to $0.0296 \mathrm{~km}^{2}$ on 19 June 2008 (ALOS/AVNIR2). Immediately prior to the GLOF, it doubled in size to $0.0422 \mathrm{~km}^{2}$ between 13 June and 24 July 2008. In water volume, as determined from DEMs of the lake areas before and after the outburst (Leica RTK-GPS900 data, 13 June 2008 Landsat ETM+, and 19 June 2008 ALOS/AVNIR-2), in just 2.5 months, this glacier lake stored and discharged more than $437000 \mathrm{~m}^{3}$ of water. The lake volume had increased to more than $237000 \mathrm{~m}^{3}$ (including the present glacier lake volume) on 13 June 2008, and between 13 June and 24 July 2008,

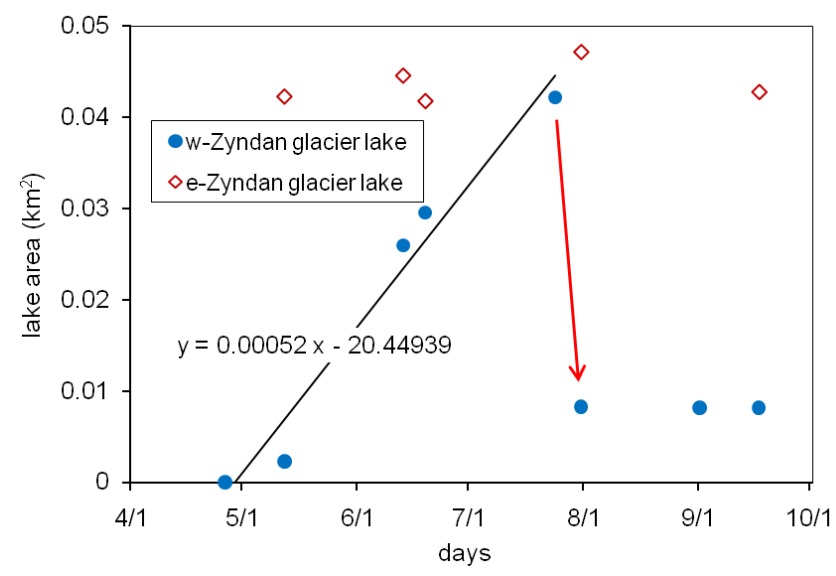

Fig. 6. Area changes of the w-Zyndan and e-Zyndan glacier lakes from April to October 2008.

an additional $200000 \mathrm{~m}^{3}$ were added. This sudden expansion of the w-Zyndan glacier lake was more rapid than normally observed for hazardous glacier lakes and is in sharp contrast to the slower growing e-Zyndan glacier lake (Figs. 5 and 6). The daily expansion rate of $0.0005 \mathrm{~km}^{2} /$ day over 10 days for the w-Zyndan glacier lake is on the same order of magnitude as the annual expansion rate of the e-Zyndan glacier lake $\left(0.0053 \mathrm{~km}^{2} /\right.$ year $)$ and the largest glacier lake $\left(0.0059 \mathrm{~km}^{2} /\right.$ year $)$ in the Kara-Say river of the Kungöy AlaToo range, as documented by Narama et al. (2009). The w-Zyndan lake level was rising $\sim 30 \mathrm{~cm}$ per day before the outburst. The runoff contribution of the catchment above the lake, which was stored in the latter, was more than $0.086 \mathrm{~m}^{3} / \mathrm{s}$ between 12 May and 13 June 2008 , and was $0.056 \mathrm{~m}^{3} / \mathrm{s}$ between 13 June and 24 July 2008.

\subsection{Outburst of the w-Zyndan glacier lake}

The water level of the w-Zyndan glacier lake was at $3761 \mathrm{~m}$ a.s.l. before the catastrophic drainage (Fig. 7). During the outburst, the water level dropped by $21 \mathrm{~m}$. The lake area was $0.0422 \mathrm{~km}^{2}$ ( $380 \mathrm{~m}$ long; $155 \mathrm{~m}$ wide) before the outburst, and reduced to $0.0083 \mathrm{~km}^{2}$ (180 $\mathrm{m}$ long; $65 \mathrm{~m}$ wide) after the event (Fig. 6). The change in water volume between immediately before and after the event was $437000 \mathrm{~m}^{3}$. The discharged water volume from the w-Zyndan glacier lake was around nine times the $50000 \mathrm{~m}^{3}$ of water involved in the GLOF that devastated the village of Shahimardan in the Alay range in 1998, killing more than 100 inhabitants (UNEP, 2007).

The w-Zyndan glacier lake is in contact with the glacier ice on its right bank (Fig. 7). The ice shoreline that undercuts the glacier ice $(60 \mathrm{~cm}$ high and $50 \mathrm{~cm}$ deep) indicates the maximum lake level before the outburst (Fig. 8a). Traces of a water channel across the terminal moraine are evidence that lake water overflowed here briefly before occupying the main 


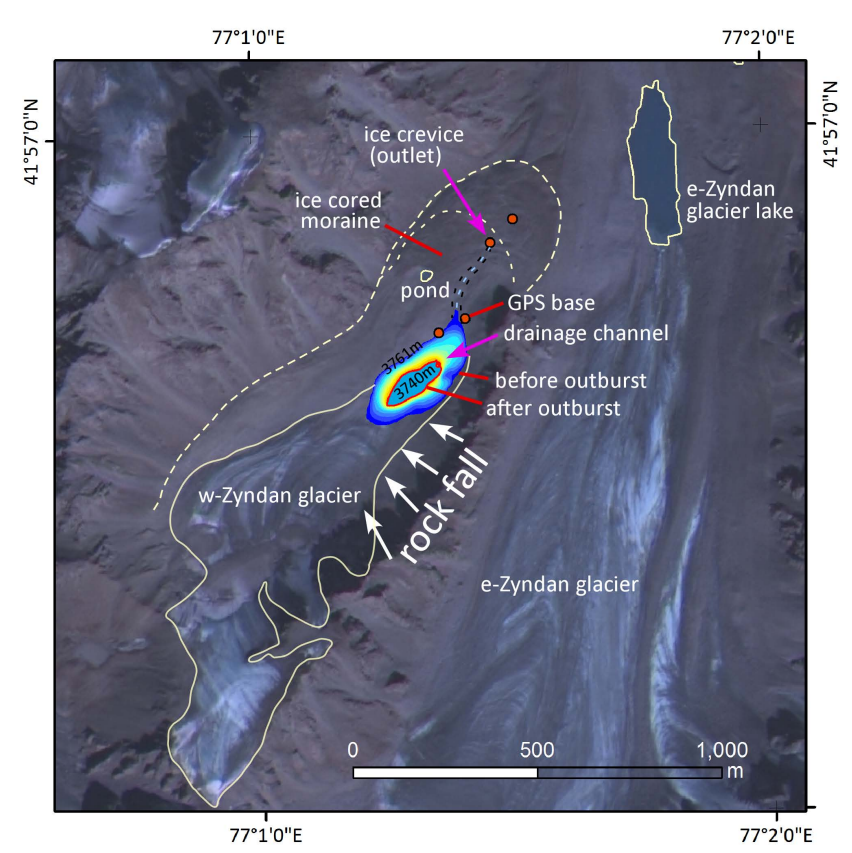

Fig. 7. Area changes in the w-Zyndan glacier lake before and after the 24 July 2008 outburst. Black numbers indicate the elevations of the lake level.

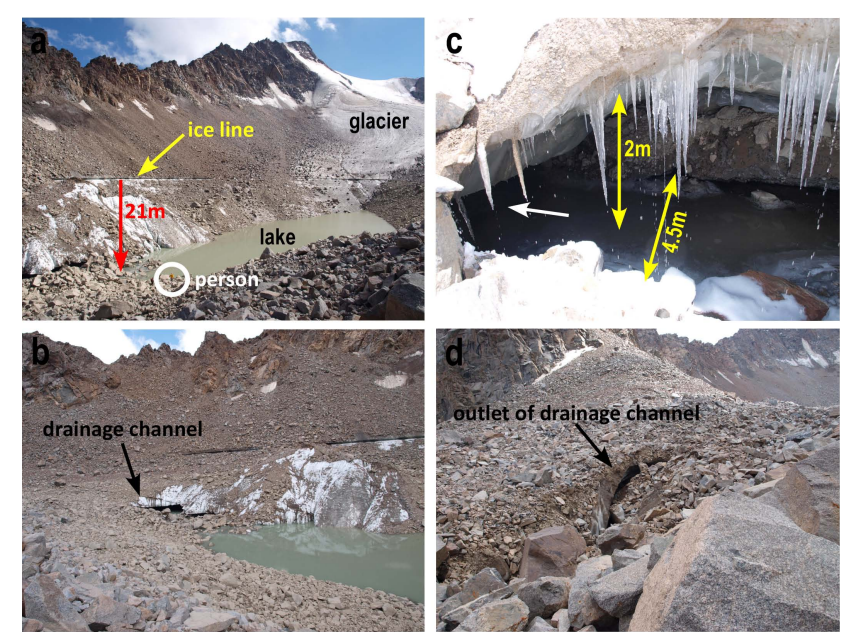

Fig. 8. Photos around the w-Zyndan glacier lake. (a) The w-Zyndan glacier lake after the lake outburst of 24 July 2008 (29 July 2008 by C. Narama). (b) The Ice shore line and drainage channel of the wZyndan glacier lake (29 July 2008 by C. Narama). (c) The drainage channel through the dead ice under the terminal moraine (18 July 2009 by C. Narama). (d) Ice crevice in the terminal moraine providing the downstream outlet (29 July 2008 by C. Narama).

drainage channel through the dead ice. The terminal moraine is $20-25 \mathrm{~m}$ above the lake water level, and although small in scale, it contains thick dead ice that contributed to dam the lake. An ice cave in the lower part of this moraine shows that lake water discharged through an ice drainage channel

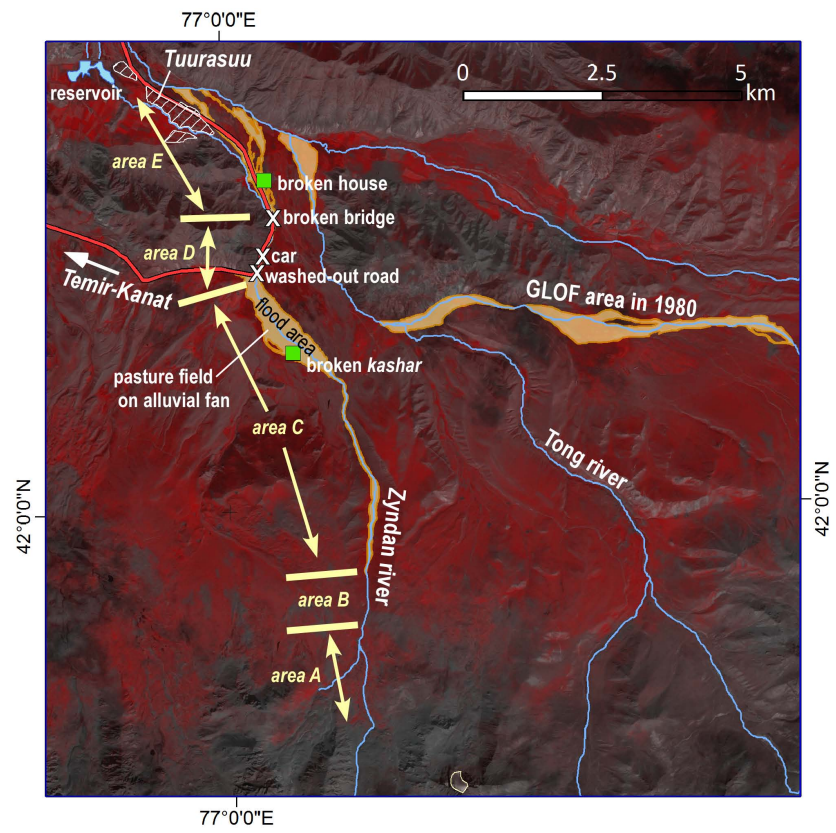

Fig. 9. Downstream flooded areas by the GLOFs in 1980 (AngySay) and 2008 (w-Zyndan), and location of selected damages of the 2008 flood.

(Fig. 8b, c). A narrow ice crevice from which the lake water discharged was found in the outer slope of the moraine (Fig. 8d). This ice-drainage channel was $350 \mathrm{~m}$ in length from the lake to the ice crevice at the outlet.

\subsection{Course of events for the 2008 GLOF and resulting damage}

The w-Zyndan glacier lake outburst occurred at around 16:00 on 24 July 2008, accompanied by a loud explosion heard down-valley by local people. The subsequent flood inundated houses, roads, and fields downstream. In the uppermost part of the flood path, the outbursting water flowed through a channel at the orographic left side of the valley, between a debris-covered dead ice zone and the bedrock (Fig. 3). In area-A (Fig. 9), lack of erosion and deposition on the river bed indicates that the flood water rapidly flowed over the small slope gradient. Area-B, with steep channel gradient, is a typical erosion area. The flood water eroded the narrow valley side slopes, and acquiring much sediment. An average slope of $11^{\circ}$ was found to be the critical channel gradient for a flood wave to become a debris flow in a lake outburst in the Swiss Alps (Huggel et al., 2002). The flood water flowed downstream as debris flow from area-C. Most boulders of 1-2 $\mathrm{m}$ diameter were deposited on the river bed and upper pastures on the alluvial fan in area-C (Figs. 9 and 10a). A shed (kashar) on the alluvial fan was damaged by huge boulders carried in the debris flow (Fig. 10b). Following the large flood, the sediment flow (high-density turbidity 
Table 1. Damages resulting from the GLOF event in 2008 from the w-Zyndan glacier lake.

\begin{tabular}{|c|c|c|c|}
\hline 1 & \multicolumn{2}{|l|}{ fatalities } & $\begin{array}{l}3 \text { of } 4 \text { people died in a car accident. The car fell in the river at around } 22: 30 \text {, six and a half } \\
\text { hours after the lake outburst, because of collapse of the road between Temir-Kanat and } \\
\text { Tuurasuu villages. } 8 \text { people were trapped on islands between the stream branches. } \\
\text { They were saved at around 02:30. }\end{array}$ \\
\hline 2 & \multicolumn{2}{|l|}{ livestock } & 4 families lost livestock ( 10 sheeps, 17 goats, 2 cows, 30 chickens, and 3 horses). \\
\hline \multirow[t]{5}{*}{3} & \multirow[t]{5}{*}{ infrastructure } & bridge & 1 bridge was destroyed around 18:00 \\
\hline & & road & Flooding and erosion of a main road. \\
\hline & & house and shed & The flood destroyed one house and a part of a shed (Kashar) \\
\hline & & irrigation & Irrigation channel between Zyndan and Tong rivers was flooded \\
\hline & & electric wire & A part of electric wire was destroyed \\
\hline 4 & \multicolumn{2}{|c|}{ agriculture and pasture fields } & $\begin{array}{l}\text { Agriculture fields (potatos and barley) and pastures were flooded and debris } \\
\text { remained on the surface. }\end{array}$ \\
\hline 5 & \multicolumn{2}{|l|}{ fish center } & $\begin{array}{l}\text { Fish center of Tong district lost } 1 \text { million fry. Dirty flood water contaminated } \\
\text { the fish water tank. }\end{array}$ \\
\hline
\end{tabular}

current) eroded the river channel along the road in area-D (Fig. 10c). Debris deposition was observed on the river bed and agriculture fields in area-E within $15 \mathrm{~km}$ from the lake. Most large sediments transported from the mountain site by debris-flow were deposited on the upper part of the alluvial fan, within $10 \mathrm{~km}$ from the lake in area-C. In this case, the total channel gradient $8.3^{\circ}$ and the ratio 1.3 of the vertical travel distance to the length of travel $(\mathrm{H} / \mathrm{L})$ were the same minimum values as found for for debris-flows in the European Alps (Chiarle et al., 2007). In the Swiss Alps, flood water from high elevation sources reached only to lowland residential areas a short distance away (Huggel et al., 2002; Chiarle et al., 2007). That is, the outbursting water had characteristics of debris flows, unlike flood waves recorded in the Bhutan Himalayas reaching $200 \mathrm{~km}$ downstream (Richardson and Reynolds, 2000). Most of GLOFs in the Tien Shan appear to be the same debris-flow type as found in the Swiss Alps.

Figure 11 presents a timeline for the GLOF event. Substantially increased river discharge consisting of clean water without debris first arrived at downstream homes $30 \mathrm{~min}$ after the beginning of the GLOF, which is assumed to have started in connection with the first loud explosion. Flow discharge was not sufficiently high to entrain additional material because the drainage channel inside the ice-cored moraine was not sufficiently open. Following a second explosion at around 18:00, dirty water with boulders, commonly $1-2 \mathrm{~m}$ in diameter, arrived at downstream areas. The boulders of the debris flow were deposited on pastures on the alluvial fan in area-C (Figs. 9 and 10a). The flood discharge continued to increase until midnight (around 01:00) on 25 July 2008, and then decreased until returning to normal discharge values at around 07:00. The flood trapped eight local residents on debris banks in branches of the braided stream system in area-
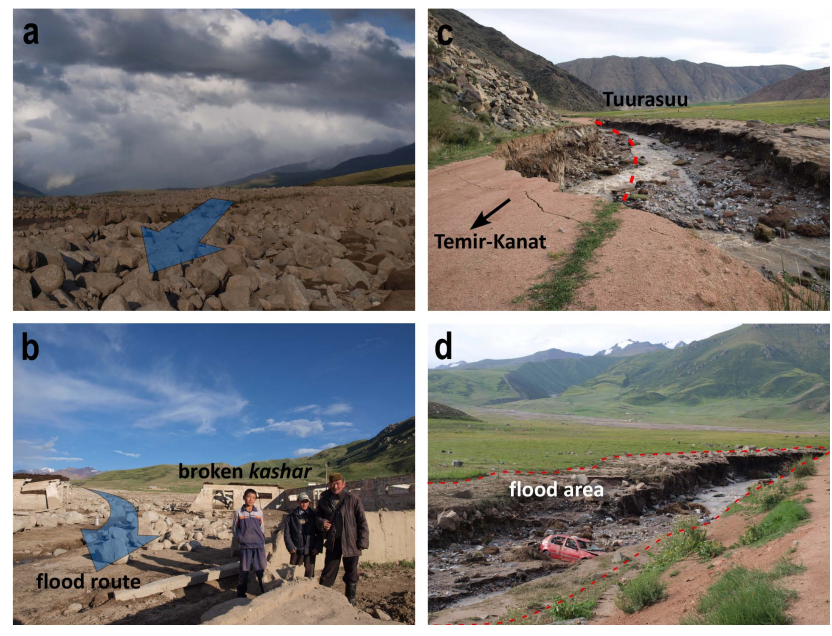

Fig. 10. Photos of damages by the GLOF. (a) 1-2-m diameter boulders deposited on the pasture fields (27 July 2008 by C. Narama). (b) A shed (Kashar) partly destroyed by the flood (27 July 2008 by C. Narama). (c) Washed-out road between the Temir-Kanat and Tuurasuu villages (27 July 2008 by C. Narama). (d) Car swept into the Zyndan river at around 22:30 (27 July 2008 by C. Narama).

E; they were finally rescued at around 02:30, 25 July, when the water level in the river dropped again. Video recordings taken from around 18:00-19:00 by local people also showed that dirty flood water (sediment flow) overflowed the river channel along the road in area-D and stranded one person on a debris bank between flooded streams in area-E (Figs. 9 and 10c, d).

We interviewed a family who lives on pastureland on the alluvial fan extending from the foot of the mountain chain (Fig. 9). Figure 10b shows their shed (kashar), part of which 


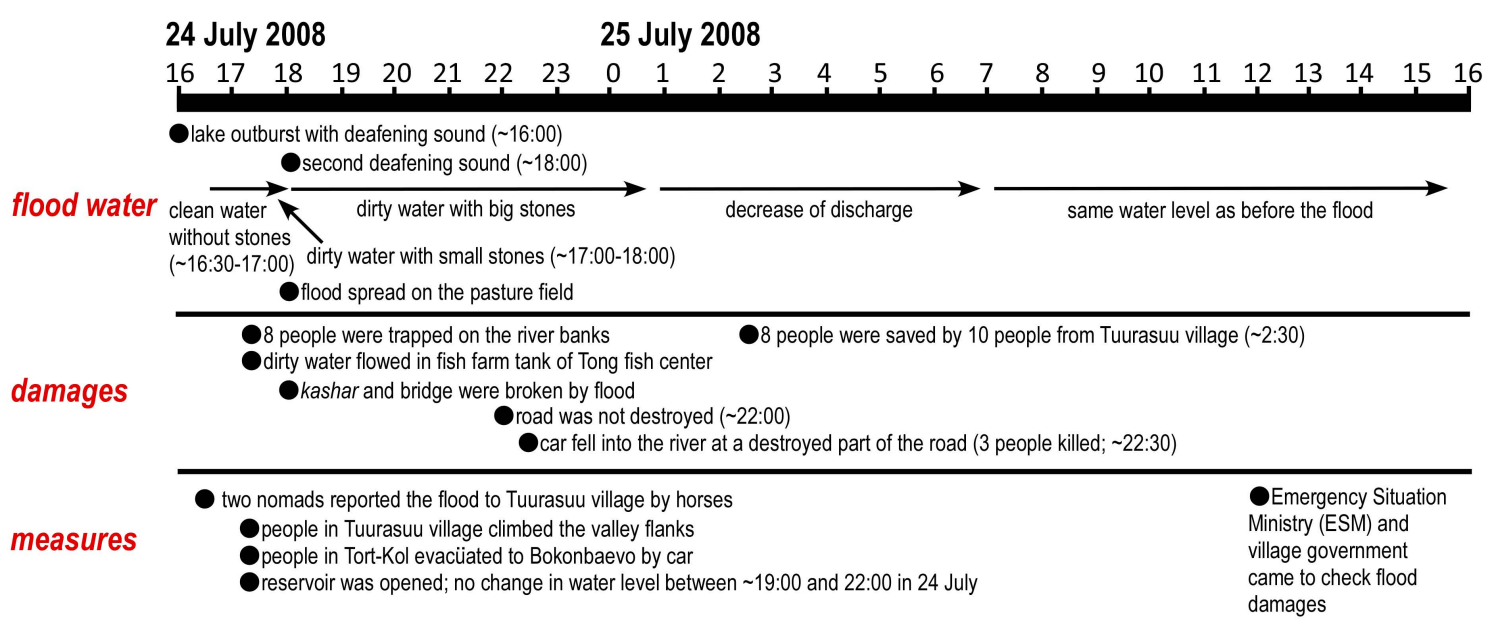

Fig. 11. Timeline for the GLOF event in 2008 of the w-Zyndan glacier lake.

was completely destroyed by the flood. They also lost seven sheep and five goats (Table 1). When the flood began, they remained at home, but after $30 \mathrm{~min}$, they waded across the still-clear flood water, which was then about $30 \mathrm{~cm}$ deep. Figure 10c and d shows the washed-out road and a car swept into the Zyndan river. This car dropped into the flood at around 22:30, about $6 \mathrm{~h}$ after the lake outburst began, at a location where the road connecting Temir-Kanat and Tuurasuu villages had collapsed due to flood erosion of the river banks (Figs. 9 and 11). Three people died in this accident. At the Tong Fish Center, approximately a million fry were being grown for future release into Lake Ysyk-köl and for sale to other areas (Fig. 2). All the fish were killed when muddy flood water mixed with the tank water. At the time of our last visit in summer 2009, the center had been unable to pay their employees' salaries since 23 September 2008, and no plans had been made to reconstruct the facility. At Tuurasuu village, where the Zyndan river flows into the reservoir, the river channel was narrow and was blocked by the deposition of huge boulders, which redirected the flood into the irrigation channel leading to the Tong river (Figs. 3 and 9). As a result, Tuurasuu and the village of Tort-Köl located downstream from the reservoir escaped serious damage. The water gate of the reservoir was opened between around 19:00 and 22:00, but there was no change in water level.

\subsection{Condition of the w-Zyndan glacier lake in 2009}

We investigated the present condition of the w-Zyndan glacier lake in summer 2009. The lake surface was frozen in mid-July 2009, and the lake area showed no significant change. The water level of the lake was $1.2 \mathrm{~m}$ lower than that after the GLOF on 24 July 2008. The ice-drainage channel of the ice-cored terminal moraine, a starting point of the flood, had collapsed, and we could observe the ice-drainage channel under the moraine that formed the lake outburst path. The ice-drainage channel was $4.5 \mathrm{~m}$ wide and $3.2 \mathrm{~m}$ high, with a water depth of $1.2 \mathrm{~m}$ in this part of the channel (Fig. 8c). The size and length of $350 \mathrm{~m}$ of the subsurface drainage tunnel and the course of the outburst event suggest that the tunnel was at least in parts already formed before the flood. Substantial flooding through subglacial tunnels from a glacierdammed lake was also reported in the Yarkant river, China (Zhang, 1992). We visited the site in the same season in 2008 and 2009, but in 2009, more snow was on the ground because of lower summer temperatures, reduced melting, and increased snowfall $(12 \mathrm{~cm}$ of snowfall was recorded during our field visit on 18 July 2009). The reduced snow and ice melt in summer 2009 due to lower temperatures might explain why the lake was $1.2 \mathrm{~m}$ lower in 2009 than in 2008 . During our 2009 visit, the water level inside the ice-drainage channel was the same as the lake level $(3737 \mathrm{~m})$, indicating a low hydraulic gradient and perhaps a vertically stabilized lake outlet.

\section{Discussion}

\subsection{State of recent glacier-lake change in the region}

This mountain region has 36 glacier lakes. These lakes are small in scale, and most showed no change or only slight expansion from 1999-2008. A factor in the slow growth of these lakes is the glacier shrinkage rate, which has been small in this region compared with that in the Pskem and IliKungöy regions of the outer Tien Shan mountains (Narama et al., 2010a). Using satellite data and our field data, we found that seven glacier lakes, including the w-Zyndan glacier lake, had produced small floods since 1999. Among these seven floods, only the flood from the w-Zyndan glacier lake produced human casualties. Some of these lakes are located in the sparsely populated southern part of the Teskey AlaToo range (Fig. 2). In that area, flood sediments from the 
Kashka-Suu river covered a road, affecting the lives of local residents (Fig. 2; No. 31). Although glacier lakes in this region are not expanding at a high rate, glacier lakes in the more populated northern part of the range pose risks of GLOFs. In that area, infrastructure and homes are located near hazard sources.

\subsection{Development of the w-Zyndan glacier lake}

Figure 12 shows the topographic profile of the w-Zyndan glacier, derived from a topographic map-derived DEM (1966), the SRTM DEM (2000), and a Leica RTK-GPS900 data-derived DEM (2008). The map DEM was generated from the 10-m contours of relevant 1:25000 topographic maps (made by the USSR using aerial photos in 1966). The three topographic profiles along the w-Zyndan glacier surface indicate substantial (up to $40-60 \mathrm{~m}$ in lake area) downwasting of the terminus since 1966. By this process, the basin developing at the terminal part could easily collect and retain meltwater from snow and ice (glacier and debris-covered dead ice). Although a small stream channel existed on the surface of the terminal moraine complex (which included much dead ice) for a short period at the time of lake expansion, glacier drainage paths are typically through or underneath the dead ice/moraine complex.

Figure 13 shows the glacier runoff in 2006-2009 in the Chong-Kyzylsuu catchment of the Teskey Ala-Too range (Fig. 1; Narama et al., 2010b). Glacier runoff was calculated using stake measurements on the Aylampa glacier and a heat balance model (Fujita and Ageta, 2000) with automatic weather station data. Glacier runoff from 1 June to 24 July 2008, when the outburst occurred, was much greater than that during the same time period in 2006, 2007, and 2009 (Fig. 13). In this region, snowmelt occurs in April to June, with the melting of glacier ice starting in June and continuing to September (Dikich and Hagg, 2004; Narama et al., 2010b). We roughly assume, therefore, that up to 13 June 2008, the glacier lake volume of more than $237000 \mathrm{~m}^{3}$ (including the present lake volume) originated mostly from snow and debris-covered dead-ice melt, and that the later volume increase by $200000 \mathrm{~m}^{3}$ stemmed, to a significant degree, from glacier ice melting between 13 June and 24 July. In fact, the Landsat 7 ETM+ images from 26 April and 12 May 2008 show much snow cover on the moraine and glacier surface; this snow had almost disappeared in the image from 13 June 2008. In addition, the sudden decline of electric conductivity (EC) value in water of the ChongKyzylsuu river shows the start of snow melt from 24-25 April 2008 in this region. Although precipitation between 1 April 2008 and 24 July 2008 was not unusually large, the mean daily temperatures from 1 May to 24 July 2008 were significantly higher than those for the same period in 2006, 2007, and 2009 (Narama et al., 2010b). These comparably high air temperatures can be assumed to have led to comparably high rates of snow and ice melting.

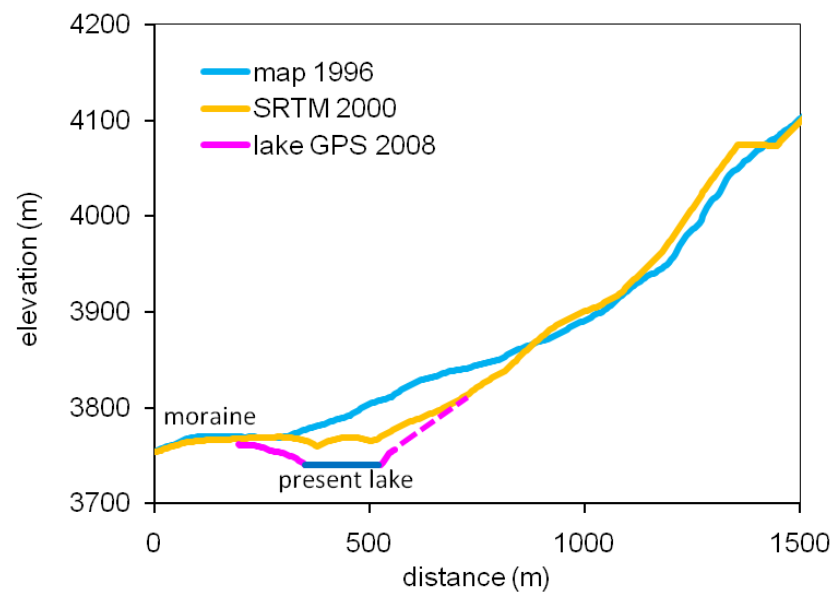

Fig. 12. Elevation profiles of the w-Zyndan glacier surface obtained from DEMs from the 1:25000 topographic map (1966), the SRTM (2000), and GPS data (2008).

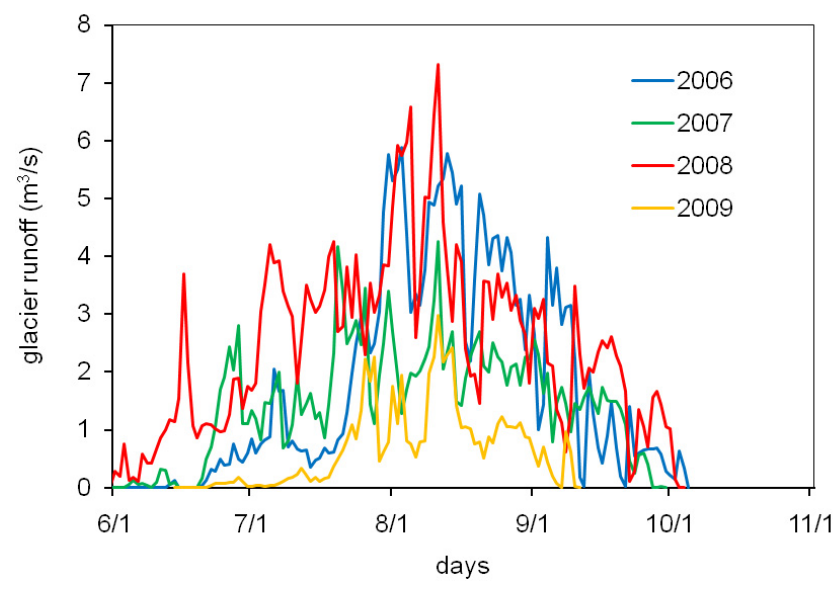

Fig. 13. The changes of glacier runoff estimated in the ChongKyzylsuu watershed (Fig. 1) during 2006-2008, based on meteorological data and stake measurements in field observation in the Aylampa glacier (Narama et al., 2010b).

In summary, we propose that the rapid rise in the lake water level was mainly due to a combination of (1) the formation of a large depression on the glacier surface at the front of the glacier, (2) the lack of a surface outlet channel draining the lake basin over the moraine complex, and (3) the unusually high snow and ice melt rates during May to July 2008. Subsurface drainage, condition (2) above, can make a glacier lake particularly prone to temporary blocking of the outlet, typically by ice channel closure due to ice deformation under overburden pressure, by ice/debris collapses into the subsurface channel(s), by blocking of inlets into the drainage system by snow banks or freezing water, or by combinations of these processes. 
From investigation of satellite data, we know that the wZyndan glacier lake first appeared as a small pond (5\% area occupation) in early May 2008. The lake had developed to $62 \%$ area occupation in 13 June 2008. Two and a half months after the lake's appearance, the GLOF occurred (Fig. 5). Such a quickly developing, short-lived lake is particularly dangerous because of the small window of opportunity to identify and monitor the lake. In remote regions, a lake could form and burst without any knowledge of the impending risk. Similar rapid lake formation was reported at the Belvedere glacier in the Italian Alps (Haeberli et al., 2002), where a supra-glacial lake developed, expanding from $\sim 3500 \mathrm{~m}^{2}$ in September 2001, to $20000 \mathrm{~m}^{2}$ in October 2001, to 20000 $40000 \mathrm{~m}^{2}$ at the end of May 2002, and to $150000 \mathrm{~m}^{2}$ in midJune 2002 (Kääb et al., 2003, 2004). The lake level rose up to $1 \mathrm{~m}$ per day, to a final volume of $3000000 \mathrm{~m}^{3}$ in mid-June 2002 (Tamburini et al., 2003). In this case, the lake was identified prior to outburst, and appropriate risk-mitigation procedures could be put in place. After slow partial drainage in autumn 2002, the lake developed again in 2003 and drained through a sub- and intra-glacial channel system. As in the case of the w-Zyndan glacier lake, a large depression formed on the Belvedere glacier surface by strong acceleration of glacier movement, and the supra-glacial lake emerged over a short period (Kääb et al., 2004). Specifically, the Belvedere glacier lake had a large area of $0.150 \mathrm{~km}^{2}$ (w-Zyndan glacier lake: $0.0422 \mathrm{~km}^{2}$ ), large expansion rate of $0.0026 \mathrm{~km}^{2} /$ day (w-Zyndan glacier lake: $0.0005 \mathrm{~km}^{2} /$ day), an extremely high rate of water level increase of $1 \mathrm{~m} / \mathrm{day}$ (w-Zyndan glacier lake: $30 \mathrm{~cm} /$ day), and a large final volume of $3000000 \mathrm{~m}^{3}$ (w-Zyndan glacier lake: $437000 \mathrm{~m}^{3}$ ). In both cases of the fast-developing lakes, they formed in connection to downwasting of the glacier surface.

\subsection{The characteristics in the outburst flood through subsurface drainage channel}

The 2008 w-Zyndan lake outburst occurred presumably as a two-phase burst of temporary blockings that affected the lake drainage system inside the terminal moraine since spring 2008. Once the first burst (indicated by the loud explosionlike sound) occurred, the flowing water could have increased the diameter of the subsurface channel(s) in the dead-ice body by water pressure and heat advection, leading to the first, 2-h-long phase of the flood (Fig. 11). However, the first burst alone clearly did not cause the catastrophic lake outburst. A second explosion-like burst at around 18:00 seems to have enlarged the discharge capacity drastically and to have caused the vastly increased catastrophic discharge until around 01:00 the next day. The change in flood discharge has the characteristics of an outburst through a subglacial drainage, and did rather not have characteristics of a flash flood, such as seen in GLOFs in the Himalayas (Vuichard and Zimmermann, 1987; Huggel et al., 2004). The outburst flood through a subglacial channel has lower peak discharges than mechanical or sudden-break failure of ice-dammed and moraine dammed lakes (Walder and Costa, 1996; Huggel et al., 2004). We calculated a peak discharge of $27 \mathrm{~m}^{3} / \mathrm{s}$ from the w-Zyndan glacier lake using an empirical equation developed for subglacial drainage of ice-dammed lakes (Walder and Costa, 1996). However, subglacial drainage from small lakes is also able to lead to serious damage such like in the case of the w-Zyandan glacier lake, because also small outburst volumes or modest peak-discharge values may result in dangerous debris flow on steep gradient channels (Haeberli, 1983). In our study region, debris-flow type GLOFs from small lakes at high elevations restricts damages to resident areas near the mountain sites as also found in the Swiss Alps (Huggel et al., 2002).

The development of the lake type discussed here appears to be rare but is also dangerous. Repeating glacier-lake outbursts may also occur through subsurface channels within dead ice. The ice drainage channels might close due to ice deformation or blockage by freezing water, especially over winter, but open again in warmer seasons. Such repeated GLOFs have occurred at several lakes in the Tien Shan (Kubrushko and Staviskiy, 1978). The Angy-Say glacier lake in the Teskey Ala-Too range (Fig. 3) and the Ak-Say glacier lake in the Kyrgyz Ala-Too range generated repeated GLOFs through the 1970s and and 1980s. In the Grubengletscher of the Swiss Alps, the proglacial lake emptied by progressive enlargement of a subglacial channel in 1968, and the same event took place in 1970 after closure of the subglacial channel during the winter (Haeberli et al., 2001). In addition, it is difficult to estimate flood timing and reservoirs of subsurface flood type by morphological or physical properties (Haeberli, 1983; Huggel et al., 2004). Significantly, in the Tien Shan, most glacial lakes are small in scale $\left(<0.01 \mathrm{~km}^{2}\right)$ and have appeared since the 1980s (Narama et al., 2009), except the Petrov glacier lake $\left(45^{\circ} 54^{\prime} 22^{\prime \prime} \mathrm{N} ; 78^{\circ} 14^{\prime} 00^{\prime \prime} \mathrm{E}\right)$. Glacier-lake sizes are related to the scales of the small moraines that formed by small alpine glaciers and that enable water pooling and lake development quickly. In the Himalayas, terminal moraine complexes that damm lakes formed often by the retreat of large-scale glaciers during the Little Ice Age and the late Holocene (Iwata et al., 2002). The large moraine sizes enable much water to be pooled during and after glacier retreat. In contrast, the terminal moraines in the study area were formed during the Little Ice Age or the 1900s; these moraines consist of fresh debris and substantial amounts of dead ice. Temporary blockages occur inside the dead ice zone in the terminal moraine. The moraines, which dam meltwater from snow and ice, contain glacier and dead-ice cores and are thus potentially unstable and influenced by water pressure and ice melt under atmospheric warming. 


\subsection{Hazard and risk management aspects}

Because the glacier lakes are small in the study region, GLOF damages have been small and localized. Most GLOFs do not cause damage up to several tens or hundreds of kilometers downstream like those in the Himalayas (Ives, 1986; Vuichard and Zimmermann, 1987; Watanabe and Rothacher, 1996). In the north part of Teskey Ala-Too range, infrastructure and settlements are located close to hazard sources, and the potential flood hazard is similar to that in the Swiss Alps (Haeberli, 1989; Huggel et al., 2002). In addition, the discharge from small glacier lakes increases relatively gradually and develops into a debris flow in this region.

An estimated $437000 \mathrm{~m}^{3}$ of lake water was discharged from the w-Zyndan glacier lake. The resulting flood killed three people and numerous livestock and inflicted heavy damage to infrastructure, crops, and pastures (Table 1). In contrast, the discharge of just $50000 \mathrm{~m}^{3}$ in the GLOF of 1998 (one-ninth the w-Zyndan GLOF volume) killed about 100 people in Shahimardan village. These differences demonstrate that the discharged water volume of a GLOF is not necessary related to the damage caused. In Shahimardan village, many of the 100 victims of the GLOF were in homes located along the river. The Zyndan river usually has relatively little water discharge, and few residents are situated along and close to the river. As noted above, the Zyndan river passes through Tuurasuu village and then into a reservoir (Figs. 3 and 9). Fortunately, huge boulders accumulated in a narrow channel section of the Zyndan river, accumulated in the Zyndan river, diverting the flood stream away from the village and thereby preventing serious damage, which otherwise would have been likely. Flooding of the reservoir and the subsequent overflow might also have led to serious problems farther downstream in Tort-Köl village. Clearly, land use needs to be carefully considered in any area prone to GLOF-related flooding. Certain areas in the flood reaches of glacier lakes should be avoided as house sites. However, vulnerable areas are difficult to identify accurately because secondary blockages can have large impacts on the flood route. The consequences of GLOFs depend on interactions among course of processes and secondary events, the types of land use downstream, and the locations of homes.

Long-time residents in Tuurasuu village remembered the GLOF events in the 1970s and 1980s from the Angy-Say glacier lake (Kubrushko and Shatrabin, 1982), and they regarded the w-Zyndan GLOF in 2008 to be of a comparable scale. Because of this past memory, some people in Tuurasuu village climbed the valley slopes during the flood event (Fig. 11). Most people living in the flooded area, however, were recent arrivals and had no knowledge of the glacier hazards. New residents and others unaware of glacier-related disasters should be provided with information and educational activities. Local people in each village should have information on the present risk condition of upstream glacier lakes. In addition, local residents should discuss approaches to early recognizing and measuring GLOFs at the village government level and be aware of when and how to escape flood-risk areas. Residents living along the river may need to evacuate to higher areas on the river terrace. Moreover, if an emergency is identified and cannot be sufficiently controlled, communication channels should be in place to warn residents. During the w-Zyndan GLOF, three people died when their car fell into the river; these deaths may have been avoided if better warning procedures had been in place. In this case, the people involved did not understand the flood situation. Communication regarding the ongoing flood was inadequate, and the road was not closed that night. This also stresses the need for systematic and integrative approaches to assessing glacier-related hazards (Kääb et al., 2005), such as remote sensing and GIS techniques. Finally, responsible authorities must understand that lakes like the w-Zyndan lake that burst out through subsurface (dead-) ice channels may in fact burst out repeatedly, every time the drainage system is blocked again. This might even happen on an annual basis until the lake damming conditions change naturally or through human intervention. Although the w-Zyndan glacier lake in mid-July 2009 was of the same size as it was directly after the 2008 GLOF, this lake should be monitored for several years.

\section{Conclusions}

Several small lake-outburst floods occurred in the 2000s in the western part of the Teskey Ala-Too range, although glacier lake expansion was not particularly large in this region. Most present glacier lakes are small. However, even such small lakes may cause serious damage in the more populated northern Teskey Ala-Too Range, where residences and infrastructure are located near hazard sources. This study shows that the combined use of various types of satellite and field data is useful for reconstructing and understanding glacier-lake development in this region. The case presented here shows a clear need to improve public awareness and preparedness concerning potential natural disasters. This is particularly important because rapidly developing, shortlived lakes such as the w-Zyndan glacier lake are difficult to detect and monitor in remote areas, making early warning extremely challenging. Lakes such as the w-Zyndan glacier lake can be recognized only by systematic and frequent areawide surveys from air or space. The w-Zyndan glacier lake had (and still has) subsurface drainage through a dead-ice rich terminal moraine; this lake type is particularly prone to repeat outbursts, and the lake should be monitored for several years. The damages caused by GLOFs in the study region were less related to the total outburst volume than to the course and combination of outburst and flood processes and to the downstream locations of residences and infrastructure relative to rivers. However, large variations in flood impacts were found among locations in the study region. This, 
together with the unpredictability of secondary blockages, highlights the need for education for glacier hazards, careful hazard zoning and land-use planning in potential risk areas. In some cases, it might be advisable to relocate homes, irrespective of the current status of potentially dangerous glacier lakes, because some lake types can develop quickly, especially under the present conditions of rapid changes in mountain glaciers and permafrost.

Acknowledgements. Special thanks are due to J. Kubota and M. Watanabe of RIHN, Narynbek uulu, K. of Institute of Seismology, Z. Engel of Charles Univ., M. Černý of the GEOMIN company, S. Yerokhin of the Government Institute of Geology and Mineral Resources, K. Fujita of Nagoya Univ. Valuable comments by F. Guzzetti, C. Huggel, and S. Richardson improved the paper. This research was partially supported by the Ministry of Education, Science, Sports and Culture, Grant-in-Aid for Young Scientists (B), 2008-2009 (No. 20700674), the Sasakawa Scientific Research Grant 2008 in Japanese Science Society, Fukutake Science and Culture Foundation 2009, Asahi Beer Scientific Research Foundation 2009, and Ili Project of RIHN. The work of A. Kääb is supported by the Research Council of Norway's International Center for Geohazards (ICG).

Edited by: F. Guzzetti

Reviewed by: S. Richardson and C. Huggel

\section{References}

Aizen, V. B., Kuzmichenok, V. A., Surazakov, A. B., and Aizen, E. M.: Glacier changes in the central and northern Tien Shan during the last 140 years based on surface and remote-sensing data, Ann. Glaciol., 43, 202-213, 2006.

Ageta, Y., Iwata, S., Yabuki, H., Naito, N., Sakai, A., Narama, C., and Karma: Expansion of glacier lakes in recent decades in the Bhutan Himalayas, in: Debris-Covered Glaciers, Proceedings of a workshop held at Seattle, Washington, USA, IAHS Publ. 246, 165-175, September 2000

Baimoldaev, T. and Vinohodov, B.: Kazselezaschita, Almaty, 2007 (in Russian).

Bolch, T.: Climate change and glacier retreat in northern Tien Shan (Kazakhstan/Kyrgystan) using remote sensing data, Global Planet. Change, 56, 1-12, 2007.

Chiarle, M., Iannotti, S., Mortara, G., and Deline, P.: Recent debris flow occurrences associated with glaciers in the Alps, Global Planet. Change, 56, 123-136, 2007.

Dikich, A. N. and Hagg, W.: Climate driven changes of glacier runoff in the Issyk-Kul basin, Kyrgystan, Zeitschrift für Gletscherkunde und Glazialgeologie, 39, 75-86, 2004.

Fateev, V. P. and Cheban, V. A.: Katalog Lednikov SSSR 14-2-4, Inventory of glaciers of the USSR 14-2-4, Leningrad, Gidrometeoizdat, 1969 (in Russian).

Fujita, K. and Ageta, Y.: Effect of summer accumulation on glacier mass balance on the Tibetan Palteau revealed by mass-balance model, J. Glaciol., 46, 244-252, 2000.

Haeberli, W.: Frequency and characteristics of glacier floods in the Swiss Alps, Ann. Glaciol., 4, 85-90, 1983.
Haeberli, W., Alean, J. C., Muller, P., and Funk, M.: Assessing the risks from glacier hazards in high mountain regions: some experiences in the Swiss Alps, Ann. Glaciol., 13, 77-101, 1989.

Haeberli, W., Kääb, A., Mühll, D. V., Teysseire, P.: Prevention of outburst floods from periglacial lakes at Grubengletscher, Valais, Swiss Alps, J. Glaciol., 47(156), 111-122, 2001.

Haeberli W., Kääb, A., Paul, F., Chiarle, M., Mortara, G., Mazza, A., Richardson, S.: A surge-type movement at Ghiacciaio del Belvedere and a developing slope instability in the east face of Monte Rosa, Macugnaga, Italian Alps, Norsk Geogr. Tidsskr., 56, 104-111, 2002.

Huggel, C., Kääb, A., Haeberli, W., Teysseire, P., and Paul, F.: Remote sensing based assessment of hazards from glacier lake outbursts: a case study in the Swiss Alps, Can. Geotech. J., 39, 316-330, 2002.

Huggel, C., Haeberli, W., Kääb, A., Bieri, D., and Richardson, S.: An assessment procedure for glacial hazards in the Swiss Alps, Can. Geotech. J., 41, 1068-1083, 004.

Ives, J. D.: Glacier lake outburst floods and risk engineering in the Himalaya, ICIMOD Occasional Paper No. 5, 1986.

Iwata, S., Narama, C., and Karma: Three Holocene and late Pleistocene glacial stages inferred from moraines in the Lingshi and Thanza village areas, Bhutan, Quatern. Int., 97/98, 69-78, 2002.

Kääb, A. and Haeberli, W.: Evolution of a high-mountain thermokarst lake in the Swiss Alps, Arct. Antarct. Alp. Res., 33(4), 385-390, 2001.

Kääb, A., Wessels, R., Haeberli, W., Huggel, C., Kargel, J. S., and Khalsa, S. J. S.: Rapid ASTER imaging facilitates timely assessment of glacier hazards and disasters, EOS T. Am. Geophys. Un., 84(13), 117-121, 2003.

Kääb, A., Huggel, C., Barbero, S., Chiarle, M., Cordola, M., Epifani, F., Haeberli, W., Mortara, G., Semino, P., Tamburini, A., and Viazzo, G.: Glacier hazards at Belvedere Glacier and the Monte Rosa east face, Italian Alps: Processes and Mitigation, Proceedings Interpraevent 2004, 1, 67-78, 2004.

Kääb, A., Huggel, C., Fischer, L., Guex, S., Paul, F., Roer, I., Salzmann, N., Schlaefli, S., Schmutz, K., Schneider, D., Strozzi, T., and Weidmann, Y.: Remote sensing of glacier- and permafrostrelated hazards in high mountains: an overview, Nat. Hazards Earth Syst. Sci., 5, 527-554, 2005, http://www.nat-hazards-earth-syst-sci.net/5/527/2005/.

Komori, J., Gurung, D. R., Iwata, S., and Yabuki, H.: Variation and lake expansion of Chubda Glacier, Bhutan Himalayas, during the last 35 years, Bull. Glaciol. Res., 21, 49-55, 2004.

Kubrushko, S. S. and Staviskiy, Y. S.: Glacier lakes of Kyrgyz and their role in mudflow formation, Data of glaciological studies, 32, 59-62, 1978 (in Russian).

Kubrushko, S. S. and Shatrabin, V. I.: Long-term prediction of glacial mudflows in Tien Shan, Data of Glaciological Studies, 43, 60-62, 1982 (in Russian).

Kudabaev, Z. I., Moldokulov, S. A., Baijumanov, D. B., Jumabaev, K. J., Abdymomunov, R. A., Kim, A. G., Koichumanova, K. D., and Nurmashev, A. K.: Regions of Kyrgyzstan, Issyk-Kul Oblast-results of the first national population census of the Kyrgyz Republic of 1999. National Statistical Committee of the Kyrgyz Republic, Bishkek. 2001.

Kutuzov, S. and Shahgedanova, M.: Glacier retreat and climatic variability in the eastern Terskey-Alatoo, inner Tien Shan between the middle of the 19th century and beginning of the $21 \mathrm{st}$ 
century, Global Planet. Change, 69, 59-70, 2009.

Narama, C., Shimamura, Y., Nakayama, D., and Abdrakhmatov, K.: Recent changes of glacier coverage in the western TerskeyAlatoo Range, Kyrgyz Republic, using Corona and Landsat, Ann. Glaciol., 43, 223-229, 2006.

Narama, C., Severskiy, I., and Yegorov, A.: Current state of glacier changes, glacial lakes, and outburst floods in the Ile Ala-Tau and Kungöy Ala-Too ranges, northern Tien Shan Mountains, Annals of Hokkaido Geography, 84, 22-32, 2009.

Narama, C., Kääb, A., Duishonakunov, M., and Abdrakhmatov, K.: Spatial variability of recent glacier area changes in the Tien Shan Mountains, Central Asia, using Corona ( 1970), Landsat ( 2000), and ALOS ( 2007) satellite data, Global Planet. Change, 71, 42-54, 2010a.

Narama, C., Fujita, K., Duishonakunov, M., Kajiura, T., Daiyrov, M., Usubaliev, R., and Shatravin, V.: Observation of glacier melting in the Chong-Kyzylsuu basin, Kyrgyzstan in 20062009, Project report on an oasis-region, 8(1), 97-104, 2010b (in Japanese).

Paul, F. and Haeberli, W.: Spatial variability of glacier elevation changes in the Swiss Alps obtained from two digital elevation models, Geophys. Res. Lett., 35, L21502, doi:10.1029/2008GL034718, 2008.

Richardson, S. D. and Reynolds, J. M.: An overview of glacial hazards in the Himalayas, Quatern. Int., 65/66, 31-47, 2000.
Tamburini, A., Mortara, G., Belotti, M., and Federici, P.: The emergency caused by the "Short-lived Lake" of the Belvedere Glacier in the summer 2002 (Macugnaga, Monte Rosa, Italy), Studies, survey techniques and main results, Terra glacialis, 6, 37-54, 2003.

UNEP: Global Outlook for Ice and Snow, UNEP, 235 pp., 2007.

Vuichard, D. and Zimmermann, M.: The 1985 catastrophic drainage of a moraine-dammed lake, Khumbu Himal, Nepal: Cause and consequences, Mt. Res. Dev., 7, 81-110, 1987.

Walder, J. S. and Costa, J. E.: Outburst floods glacier-dammed lakes: The effect of mode of lake drainage on flood magnitude, Earth Surf. Proc. Land., 21, 701-723, 1996.

Watanabe, T. and Rothacher, D.: The 1994 Lugge Tsho glacial lake outburst flood, Bhutan Himalaya, Mt. Res. Dev., 16, 77-81, 1996.

Yerokhin, S.: Data report of glacial lakes in 2000-2008, 2008 (in Russian).

Zabirov, R. D. and Sidikov, D. J.: Katalog Lednikov SSSR 14-2-5, Inventory of glaciers of the USSR 14-2-5, Leningrad, Gidrometeoizdat, 1976.

Zhang, X.: Investigation of glacier bursts of the Yarkant River in Xinjiang, China, Ann. Glaciol., 16, 135-139, 1992. 